\title{
Effect of diet and genotype on carcass characteristics of feedlot hair sheep
}

\section{Roberto Germano Costa ${ }^{1}$, José Teodorico de Araújo Filho ${ }^{2}$, Wandrick Hauss de Sousa ${ }^{3}$, Severino Gonzaga Neto ${ }^{4}$, Marta Suely Madruga ${ }^{5}$, Angelina Bossi Fraga ${ }^{2}$}

\author{
${ }^{1}$ Departamento de Agropecuária, Universidade Federal da Paraíba (DAP/CCHSA/UFPB), Bananeiras, Paraíba, Brasil. \\ 2 Centro de Ciências Agrárias, Universidade Federal de Alagoas (CECA/UFAL), Maceió, Alagoas, Brasil. \\ ${ }^{3}$ Empresa Estadual de Pesquisa Agropecuária da Paraíba (EMEPA), João Pessoa, Paraíba, Brasil. \\ ${ }^{4}$ Departamento de Zootecnia, Universidade Federal da Paraíba (DZ/UFPB), Areia, Paraíba, Brasil. \\ ${ }^{5}$ Departamento de Tecnologia e Química de Alimentos, Universidade Federal da Paraíba (DTQA/CT/UFPB), João Pessoa, Paraíba, Brasil.
}

ABSTRACT - It was evaluated qualitative characteristics of confined hair sheep submitted to diets with two energy levels. Eighteen lambs from each genotype were used: Morada Nova, Santa Inez and Dorpper $\times$ Santa Inez crossbreds. The rations with the lowest and the highest energy level were made up with 2.5 and 2.94 Mcal EM/kg DM, respectively. It was evaluated conformation and finishing carcass, in addition to leg tissue composition. The score for conformation was significantly higher for animals kept in diet with the highest energy level and for Dorpper $\times$ Santa Inês crossbreds. Animals from Santa Inez and from Dorpper $\times$ Santa Inez breeds showed score for meat color close to red class, while Morada Nova genotype was close to slightly dark red. The muscle:bone ratio for Dorpper $\times$ Santa Inez crossbred and Morada Nova animals was higher than for Santa Inez animals. The muscle:fat ratio was higher in animals kept with the lowest energy concentration diet. The rib eye area of Dorpper $\times$ Santa Inez crossbred animals was similar to Morada Nova animals and higher than Santa Inez group. Carcass compactness index and subcutaneous fat thickness and maximum cover fat thickness on the surface of the $12^{\text {th }}$ rib were higher for animals submitted to the diet with the highest energy level. Leg fat was the only tissue influenced by diet calory density, while bone tissue was affected by the genotypes, since Santa Inez breed showed the highest percentage in this tissue. The genotype and level of energy in the diet affect carcass conformation. Diets with higher energy density improve carcass compactness index and subcutaneous fat thickness.

Key Words: muscularity index, rib eye area, tissue composition

\section{Efeito de dietas e genótipos sobre as características de carcaça de cordeiros deslanados em confinamento}

RESUMO - Avaliaram-se as características qualitativas da carcaça de cordeiros deslanados em confinamento submetidos a dietas com dois níveis de energia. Foram utilizados 18 cordeiros de cada genótipo: Morada Nova, Santa Inês e mestiços Dorper × Santa Inês. As rações de menor e maior nível energético foram constituídas de 2,5 e 2,94 Mcal EM/kg MS, respectivamente. Foram avaliados a conformação e acabamento da carcaça, além da composição tecidual da perna. O escore para conformação foi significativamente maior nos animais mantidos com a dieta de maior nível de energia e nos mestiços Dorper $\times$ Santa Inês. Animais dos grupos Santa Inês e Dorper $\times$ Santa Inês apresentaram escore para cor da carne próximo à classe de vermelho, enquanto no genótipo Morada Nova foi próximo ao vermelho levemente escuro. A relação músculo:osso dos mestiços Dorper × Santa Inês e dos Morada Nova foi superior à observada no grupo Santa Inês. A relação músculo:gordura foi maior nos animais mantidos com a dieta de menor concentração energética. A área de olho-de-lombo dos mestiços Dorper $\times$ Santa Inês foi semelhante à do grupo Morada Nova e superior à do grupo Santa Inês. O índice de compacidade da carcaça, a espessura de gordura subcutânea e a espessura de gordura de cobertura sobre a superfície da $12 \underline{a}$ costela foram maiores nos animais submetidos à dieta de maior nível energético. A gordura da perna foi o único tecido influenciado pela densidade calórica das dietas, enquanto o tecido ósseo sofreu influência dos genótipos, uma vez que a raça Santa Inês apresentou o maior percentual desse tecido. O genótipo e o nível de energia da dieta influenciam a conformação de carcaça. Dietas com maior densidade energética melhoram o índice de compacidade da carcaça e espessura de gordura subcutânea.

Palavras-chave: área de olho-de-lombo, composição tecidual, índice de musculosidade 


\section{Introduction}

The consumption of sheep meat in the country is still very low, both in absolute and in comparative values in relation to other meat. The production and marketing sectors for sheep meat in recent years have shown great effort to enlarge the market, always keeping the concern for quality in mind. According to Siqueira et al. (2001), among the various quality indicators, carcass weight stands out, being usually pre-determined in accordance with the preferences of the consumer market.

The standardization of lamb carcasses to be made available in market is needed to enhance the product and to attract the consumer. Carcasses must present high percentage of muscle, uniform coverage of subcutaneous fat, and fat content according to the market demands, features defined by the maturity level of the genotype (Bueno et al., 2000). The amount of fat is currently considered an important aspect in the meat market in function of its relationship with health problems; on the other hand, in sheep, fat is the component with the largest variability in the carcass, and the fat thickness is linked to several factors, among them, breed, sex, diet, feeding period and carcass weight.

The carcass finishing level is affected by the nutritional status of the animal. Therefore, animals that receive full rations can be slaughtered earlier and with higher quality carcasses. Carvalho et al. (1980) report that the use of diet with high energy intake and industrial crossings can provide benefits to the carcass and meat quality.

Overall, meat-specialized breeds present rapid growth and good carcass finishing, but are not always found in different regions in Brazil; therefore, many or most are not suitable to weather adversities. On the other hand, the native sheep, whose main representatives are Santa Inez and Morada Nova breeds, are genetic groups with distinct weight performance and carcass characteristics and, only recently have been drawing attention from researchers and breeders from different regions of Brazil. Santa Inez breed has already become a reality and, hence, has conquered space in all regions of the country. Morada Nova breed, submitted to the natural selection process, has not attracted the attention from the academic community for more studies on its potential yet.

This study aimed to evaluate the effects of two diets (2.50 and $2.94 \mathrm{Mcal} \mathrm{EM} / \mathrm{kgDM}$ ) and three genotypes (Morada Nova, Santa Ines and Dorpper $\times$ Santa Inez crossbreed) on the carcass quality characteristics and tissue composition of lambs finished in feedlot.

\section{Material and Methods}

This study was conducted in the semiarid region in

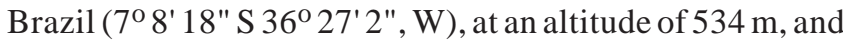
average temperature of $30^{\circ} \mathrm{C}$. Fifty-four lambs of Morada Nova, Santa Inez and F1 (Dorpper $\times$ Santa Inez) breeds , 18 animals from each genotype, were used. Morada Nova animals were, on average, at 150 days of age and $14.98 \pm 2.80 \mathrm{~kg}$ in weight. Santa Inez and Dorpper $\times$ Santa Inez genotypes were, on average, at 100 days of age and average weight of $17.63 \pm 1.48$ and $17.80 \pm 1.52 \mathrm{~kg}$, respectively.

The period of adaptation to stalls and diets was of 14 days, during which the animals were vaccinated against clostridiosis and $1 \%$ moxidectin-based parasiticide orally applied, with repetition 15 days after the first dose.

Two diets based on NRC (1985) containing energy levels of $2.50 \mathrm{Mcal}$ EM/kg DM and 2.94 Mcal EM/kg DM were formulated. The bulky was composed of crushed tifton hay (Cynodon spp). The ration, as complete diets, was composed of enriched palm meal (Opuntia sp), soybean meal, corn, urea and mineral (Table 1). The animals were divided into groups of three per stall, remaining under confinement until reaching aproximately $30 \mathrm{~kg}$ of body weight. The lambs had free access to food and water, received diets ad libidum throughout the experimental phase, which were supplied twice daily.

When reached the slaughter weight, the animals were weighted to obtain the final weight (FW). Then, they were submitted to a 16-hour solid fasting period and, after that time, they were weighted again, resulting in the slaughter live weight (SLW). The slaughter technique was carried out

Table 1 - Composition of diets used in feeding experiments with lambs of three genotypes

\begin{tabular}{lcc}
\hline Ingredient (\%) & \multicolumn{2}{c}{ Energy level } \\
\cline { 2 - 3 } & 2.50 Mcal & 2.94 Mcal \\
& EM/kgDM & 50.5 \\
\hline Corn bran & 25.0 & 15.0 \\
Soybean meal & 10.0 & 14.0 \\
Enriched palm meal & 33.0 & 19.0 \\
Tifton hay & 30.5 & 1.0 \\
Urea & 1.0 & 0.5 \\
Mineral salt & 0.5 & \\
Chemical composition (\%) & & 90.4 \\
Dry matter & 90.9 & 19.6 \\
Crude protein & 18.6 & 13.2 \\
Mineral matter & 14.5 & 33.6 \\
Neutral detergent fiber & 41.7 & 13.7 \\
Acid detergent fiber & 19.6 & 81.7 \\
Total digestible nutrients & 69.4 & 2.95 \\
Ether extract & 2.32 & 2.95 \\
Metabolizable energy (Mcal/kgDM) & 2.50 & \\
\hline
\end{tabular}

${ }^{1}$ Calculated according to NRC (1985). 
through stunning by cerebral concussion, followed by bleeding, skinning and gutting, the carcasses were cooled according to methodology described by Sañudo et al., (2000).

At the end of the cooling period, the carcasses were sent to a refrigerated room, where they were weighed and the conformation classified according to Osorio \& Osorio (2003), with scores ranging from one to five with 0.5 -intervals, making nine categories. Scores 1.0 and 1.5 are classified as poor minus and poor, scores 2.0 as regular, scores 2.5, 3.0 and 3.5 classified as good minus, good and good plus and scores 4.0 , 4.5 and 5.0 classified as very good minus, very good and very good plus, respectively. After assessment, the carcasses were divided lengthwise at the midline into two antimers. In the half left carcass, a cross cut was made between the $12^{\text {th }}$ and $13^{\text {th }}$ rib, exposing the cross section of the longissimus lumborum muscle, whose area was dashed using an appropriate pen on a transparent plastic film for determining the rib eye area (REA) according to Sen et al. (2004). The maximum cover fat thickness and subcutaneous fat thickness (SFT) on the $12^{\text {th }}$ rib (GR) were also measured according to Safari et al. (2001) and Kosulwat et al. (2003), respectively. To determine the rib eye area, AutoCAD software was used (Macedo et al., 2000).

Quantity, distribution and marbling texture of the longissimus lumborum muscle, as well as meat texture and coloration were determined, using five scores ranging from one to five, according to Osorio \& Osorio (2003). The texture was classified as very coarse, coarse, slightly coarse, fine and very fine. The color was classified as clear pink, pink, light red, red and dark red.

In the half right carcass, the measurement of the internal carcass length (ICL) was done with the aid of a tape measure in order to obtain the carcass compactness index $(\mathrm{CCI}=\mathrm{PCF} / \mathrm{ICL})$. The legs were used for anatomical studies. After separation from carcass they were packed in plastic bags and frozen in a freezer $\left(-20^{\circ} \mathrm{C}\right)$ for a period of seven days. After this period, they were dissected into muscles, bones, fat (subcutaneous, intramuscular and total), and other tissues (tendons, blood vessels, nerves, etc.), according to methodology of Fisher and De Boer (1994). Muscle: bone and muscle: fat ratios were then determined, and the femur length was measured in centimeters, together with the leg muscularity index (LMI), which were calculated by applying the methodology described by Purchas et al. (1991).

The experimental design was completely randomized with $3 \times 2$ factorial arrangements (three genotypes and two energy levels) with nine repetitions. The data were submitted to the analysis of variance using the PROC ANOVA of SAS $^{\mathrm{TM}}$ (1999) whose model included the effects of diet (high and low energy), genotype (Morada Nova, Santa Ines and Dorpper $\times$ Santa Inez) using the slaughter weight as covariate. The averages were compared through the Tukey test at $5 \%$ of probability.

\section{Results and Discussion}

The carcass conformation is defined as the thickness of muscle and subcutaneous fat in relation to the size of the skeleton. The diet with higher energy density presented higher scores, with difference of $13.3 \%$ in relation the low density (Table 2). Colomer-Rocher et al. (1988) refer to conformation as a term used to describe the form of the carcass and to translate the visual impression that it causes in the observer. In sheep and cattle, breed and subcutaneous fat are the factors that affect the carcass conformation most.

Among the genetic groups, the one showing the highest carcass conformation scores was Dorpper $\times$ Santa Inez

Table 2 - Quality characteristics of carcass from Morada Nova, Santa Inez and Dorpper $\times$ Santa Inez crossbreed lambs submitted to diets with two energy content

\begin{tabular}{|c|c|c|c|c|c|c|}
\hline \multirow[t]{2}{*}{ Variable } & \multicolumn{2}{|c|}{ Diet (Mcal EM/kg DM) } & \multicolumn{3}{|c|}{ Genotype } & \multirow[t]{2}{*}{$\mathrm{CV}^{1}(\%$} \\
\hline & 2.50 & 2.94 & $\mathrm{MN}$ & SI & $\mathrm{D} \times \mathrm{SI}$ & \\
\hline Slaughter weight & 28,61 & 29,62 & 28,53 & 29,09 & 29,72 & 7,53 \\
\hline Conformation & $3.13 b$ & $3.61 \mathrm{a}$ & $3.11 \mathrm{~b}$ & $3.17 \mathrm{~b}$ & $3.83 a$ & 11.97 \\
\hline Finishing level & 3.19 & 3.45 & $3.09 \mathrm{~b}$ & $3.23 b$ & $3.64 a$ & 13.24 \\
\hline \multicolumn{7}{|l|}{ Marbling } \\
\hline Quantity & 1.42 & 1.33 & 1.50 & 1.33 & 1.29 & 62.08 \\
\hline Distribution & 1.11 & 1.00 & 1.28 & 0.89 & 1.00 & 55.79 \\
\hline Texture & 2.55 & 2.52 & 2.61 & 2.50 & 2.50 & 42.55 \\
\hline \multicolumn{7}{|l|}{ Meat } \\
\hline Color & 3.81 & 3.78 & $3.55 b$ & $3.94 \mathrm{a}$ & $3.89 a$ & 7.56 \\
\hline Texture & 4.85 & 4.78 & 4.89 & 4.78 & 4.78 & 8.35 \\
\hline
\end{tabular}

Mean values in the same line and within each factor with a different lowercase letter differ significantly $(\mathrm{P}<0.05)$.

${ }^{1}$ Percentage of coefficient of variation. 
crossbreed, above Morada Nova and Santa Ines in 18.80 and $17.23 \%$ respectively. These results are similar to those found by Carvalho et al. (1980), who observed that the use of a better diet and industrial crossing can provide significant changes in the quality characteristics of carcasses. However, the finishing level of the carcass from Morada Nova genotype should be valued because it is a native breed that shows potential for improvement for meat production in the Semi-arid region, although these animals were aged a bit higher than other breeds

On the other hand, Cartaxo et al. (2008) and Cezar (2004) worked with Santa Inez and Dorpper $\times$ Santa Inez crossbreed genotypes developed in the Brazilian semi-arid region and found no significant effect $(\mathrm{P}>0.05)$ for carcass conformation in Santa Inez and Dorpper $\times$ Santa Inez crossbreed lambs.

No significant effect $(\mathrm{P}>0.05)$ of diets on the carcass finishing was observed either. This would not be an expected result since the carcass finishing level is also affected by the nutritional level. Probably, the differences in the energy levels of diets were not sufficient to highlight differences in this feedlot time. According to Furusho-Garcia et al. (2000), in higher nutritional levels, the animal could be slaughtered sooner and with better carcass quality.

Genotypes were responsible for differences $(\mathrm{P}<0.05)$ in the carcass finishing. Dorpper $\times$ Santa Inez crossbreed presented higher average values, compared to Morada Nova and Santa Ines breeds. This superiority may be the result of the heterosis effect from crossed animals. However, it is important to highlight the potential for meat production of native breeds studied for semi-arid region. On the other hand, Siqueira and Fernandes (2000) worked with confined lambs and found no significant differences between genotypes, in relation to the finishing level.

The effect of diet and genotype was not significant $(\mathrm{P}>0.05)$ for marbling in none of the variables (quantity, distribution and texture), corroborating with results obtained by Cézar (2004) and Cartaxo et al. (2008), who worked with Santa Inez and Dorpper $\times$ Santa Inez crossbreed lambs and found no significant difference for these variables. The deposit of small amount of intramuscular fat is an intrinsic feature in the sheep species (Cezar, 2004).

Meat color suffered no significant influence from diets $(\mathrm{P}>0.05)$. The average score of 3.79 can be classified as red. This classification has been the one of greatest preference by sheep meat consumers and thus the one that best meet the most demanding market niche (Sañudo et al., 2000). Genotypes exerted significant influence $(\mathrm{P}<0.05)$ on the meat colour variable. Santa Inez and Dorpper $\times$ Santa Inez crossbreed genotypes had similar scores among themselves and above the score obtained by Morada Nova native breed. The scores 3.94 for Santa Inez and 3.89 for Dorpper $\times$ Santa Inez are very close to the red classification. On the other hand, the score for meat color of 3.55 for Morada Nova native breed is closer to light red classification. This result may have occurred due to the intrinsic differences among each genetic group.

The diet did not affect meat texture $(\mathrm{P}>0.05)$. The results of these scores were close to 5 , allowing a texture classification for the meat of these animals from fine to very fine. This may indicate superiority of the meat texture of the animals under study.

Regarding to carcass muscularity level, muscle: bone ratio was influenced by genotype $(\mathrm{P}>0.05)$ (Table 3$)$. Santa Inez genotype presented ratios of $14.19 \%$ and $11.76 \%$, lower than Morada Nova and Dorpper $\times$ Santa Inez crossbreed. Oliveira et al. (1998) researched five genotypes and obtained higher muscle: bone ratio for breeds more specialized in meat production.

Muscle:fat ratio was influenced by the energy density of diets $(\mathrm{P}<0.05)$. Animals that received diet with a higher energy level accumulated greater amount of fat, reflecting the lower muscle:fat ratio. No significant difference $(\mathrm{P}>0.05)$ between the genetic groups for the muscle:fat ratio was observed. Probably, this observation is attributed to the fact that fat tissue presents slow growth in the first months

Table 3 - Muscularity level and characteristics assessed in the carcass of lambs submitted to diets with two energy contents

\begin{tabular}{|c|c|c|c|c|c|c|}
\hline Parameter ${ }^{1}$ & \multicolumn{2}{|c|}{ Diet (Mcal EM/kg DM) } & \multicolumn{3}{|c|}{ Genotype } & $\mathrm{CV}^{2}(\%)$ \\
\hline Muscle:bone ratio & 3.13 & 3.16 & $3.30 \mathrm{a}$ & $2.89 \mathrm{~b}$ & $3.23 a$ & 8.91 \\
\hline Leg muscularity index & 0.41 & 0.40 & $0.40 \mathrm{~b}$ & $0.39 b$ & $0.43 a$ & 5.59 \\
\hline Rib eye area $\left(\mathrm{cm}^{2}\right)$ & 10.93 & 11.41 & $11.17 \mathrm{ab}$ & $10.39 b$ & $11.94 \mathrm{a}$ & 11.97 \\
\hline Carcass compactness index $(\mathrm{kg} / \mathrm{cm})$ & $0.23 \mathrm{~b}$ & $0.26 \mathrm{a}$ & 0.24 & 0.24 & 0.25 & 8.39 \\
\hline
\end{tabular}

${ }^{1} \mathrm{GR}$ : maximum cover fat thickness on the surface of the $12^{\text {th }}$ rib.

2 Percentage of coefficient of variation

Mean values in the same row and within each factor with a lowercase letter differ significantly $(\mathrm{P}<0.05)$ 
of life, and the hair genotypes accumulated lesser amount of fat in their carcasses.

Energy density of diets did not influence $(\mathrm{P}>0.05)$ the leg muscularity index. The effect of genotype on the leg muscularity index was significant $(\mathrm{P}<0.05)$, and the index in the Dorpper $\times$ Santa Inez crossbreed was higher than that of Santa Inez and Morada Nova breeds. Cartaxo et al. (2008), who studied Santa Inez and Dorpper $\times$ Santa Inez crossbreed lambs, also found significant difference between genotypes on the muscularity index, with values ranging from 0.36 to 0.43 , close to those found in this study.

The rib eye area was not influenced $(\mathrm{P}>0.05)$ by diet maybe because animals are slaughtered at an early age (younger than six months of age) and because of the slow growth of the longissimus muscle. In relation to the genotype effect, means were significantly different $(\mathrm{P}<0.05)$, and Dorpper $\times$ Santa Inez crossbreed was above Santa Inez and Morada Nova and close to other two genotypes. Different results were obtained by Siqueira \& Fernandes (2001), Cézar (2004) and Cartaxo et al. (2008), who found no significant differences between genotypes for this variable.

Carcass compactness is the index that assesses the relationship between carcass weight and carcass length, showing the amount of tissue deposited in the carcass. The effect of diet on the carcass compactness index was significant $(\mathrm{P}<0.05)$. The diet of highest energy level presented carcass compactness index $11.54 \%$ higher. As the carcass increases in weight, it becomes relatively shorter, broader and compacter. Similar index was presented by Sa et al. (2005), who worked with Santa Ines and Hampshire Down breeds and found average carcass compactness index of $0.25 \mathrm{~kg} / \mathrm{cm}$. Genotype did not influence $(\mathrm{P}>0.05)$ carcass compactness index, and a similar result was observed by Cartaxo et al. (2008) in Santa Inez and Dorpper $\times$ Santa Inez crossbreed genotypes.

A significant difference $(\mathrm{P}<0.05)$ in the effect of diet on the subcutaneous fat thickness was observed. The diet with highest energy density presented higher subcutaneous fat thickness which was not influenced by the genotype $(\mathrm{P}>0.05)$.
The grade rule (GR) measure is performed on the surface of the $12^{\text {th }}$ rib, at eleven centimeters from the dorsolumbar line. This measurement predicts the amount of subcutaneous fat in the carcass. Cezar \& Souza (2007) worked with hair sheep in northeastern Brazil and reported that for the GR thickness to be considered as ideal, it should be found between 7 and $12 \mathrm{~mm}$, and for values below 7 , the carcass is considered to be as poor finishing and above $12 \mathrm{~mm}$, it is considered as being excessively finished. According to this classification proposed by Cezar \& Souza (2007) the carcasses of animals that received diet with higher energy density is considered of ideal finishing, while those who received diet with lower energy intake are considered as poor finishing.

Genotype did not influence this variable $(\mathrm{P}>0.05)$, probably because of the similarity of the slaughter weights of animals from this experiment; however, through the classification of Cezar \& Souza (2007), the carcass of Morada Nova genotype was classified as of ideal finishing, while carcasses of Santa Inez and Dorpper $\times$ Santa Inez crossbreed genotypes were classified as poor finishing. Gonzaga Neto et al. (2006) worked with Morada Nova lambs and also found significant differences in the grade rule measurement.

Fat was the only tissue constituent of the leg that suffered effect from diet $(\mathrm{P}<0.05)$. Animals submitted to diet with higher energy density presented $23.56 \%$ of superiority in the leg fat percentage (Table 4). The only leg-constituent tissue that showed significant differences $(\mathrm{P}<0.05)$ in function of the genotype was the bone tissue. Santa Inez breed animals showed greater percentage of this tissue, showing to be a breed of higher stature in relation to the other two breeds. These results reaffirm the lowest muscle: bone ratio in Santa Inez breed (Table 3).

The average values for muscle, bone, fat and others were $67.7,21.6,7.9$ and $2.6 \%$ respectively. These results were similar to those reported by Gonzaga Neto et al. (2006), who presented averages for muscle, bone, fat and others of 67.6, 19.9, 9.8 and 2.4\% respectively, in the tissue leg composition of Morada Nova feedlot lambs, when the effect of different forrage: concentrate ratios were evaluated.

Table 4 - Leg tissue composition of lambs submitted to diets with two energy levels

\begin{tabular}{|c|c|c|c|c|c|c|}
\hline \multirow[t]{2}{*}{ Parameter } & \multicolumn{2}{|c|}{ Diet (Mcal EM/kg DM) } & \multicolumn{3}{|c|}{ Genotype } & \multirow[b]{2}{*}{$\mathrm{CV}^{2}(\%)$} \\
\hline & 2.5 & 2.94 & Morada Nova & Santa Inez & Dorpper $\times$ Santa Inez & \\
\hline Muscle & 68.37 & 67.11 & 68.08 & 66.97 & 68.18 & 3.74 \\
\hline Fat & $7.13 b$ & $8.81 \mathrm{a}$ & 8.56 & 7.22 & 8.40 & 27.28 \\
\hline Others $^{1}$ & 2.53 & 2.71 & 2.72 & 2.53 & 2.61 & 27.08 \\
\hline
\end{tabular}

1 Tendons, nerves, blood vessels, etc.

2 Percentage of coefficient of variation.

Mean values in the same row and within each factor with a lowercase letter differ significantly. 


\section{Conclusions}

Genotype and the energy level of the diets influence conformation and finishing characteristics of sheep carcasses. Diet with higher energy density improves the carcass compactness index, subcutaneous fat thickness and maximal cover fat thickness on the surface of the $12^{\text {th }}$ rib of all studied genotypes. Dorpper $\times$ Santa Inez industrial crossing presented a set of carcass characteristics such as better conformation and finishing, lighter meat color, better muscle:bone ratio and higher leg muscularity index, which may classify this genotype as superior to others. However, the finishing level of the carcass from Morada Nova genotype should be valued because it is a native breed that shows potential for improvement for meat production in the semi-arid region.

\section{References}

CARTAXO, F.Q.; SOUSA, W.H.; CEZAR, M.F. et al. Effects of genotype group and $f$ the body condition on the performance of lambs finished in feedlot. Revista Braileira de Zootecnia, v.37, p.1483-1489, 2008.

CARVALHO, J.B.P.; PEDROSO, J.R.; FIGUEIRÓ, P.R.P. Alguns fatores que afetam o rendimento de carne ovina. Ciência Rural, v.10, p.95-104, 1980.

CÉZAR, M.F. Carcass characteristics and physiological adaptability of sheep during the phase of crepite (Características de carcaça e adaptabilidade fisiológica de ovinos durante a fase de cria). 88f. 2004. PhD in Produção Animal Universidade Federal da Paraíba, Areia.

CÉZAR, M.F.; SOUZA, W.H. Carcaças ovinas e caprinas: obtenção-avaliação- classificação. Uberaba: Ed. Agropecuária Tropical, 2007. 231p.

COLOMER-ROCHER, F.; DELAT, R.; SIERRA-ALFRANCA, I. Método normalizado para el estudio de los caracteres cuantitativos y cualitativos de las canales, según los sistemas de producción. In: Método normalizado para el estudio de los caracteres cuantitativos y cualitativos de las canales caprinas y ovinas. Madrid: Cuadernos INIA, v.17, p.19-41, 1988.

FISHER, A.V.; De BOER, H. The EAAP standard method of sheep carcass assessment. Carcass measurements and dissection procedures. Livestock Production Science, v.38, p.149-159, 1994.
FURUSHO-GARCIA, I.F.F.; PEREZ, J.R.O.; OLIVEIRA, M.V. Carcass characteristics of Texel x Bergamacia, Texel x Santa Inês and Pure Santa Inês Lambs, finished in confinement with coffee hull as a part of the diet. Revista Brasileira de Zootecnia, v.29. p.253-260, 2000.

GONZAGA NETO, S.; SILVA SOBRINHO, A.G.; ZEOLA, N.B.L. et al. Quantitative characteristics of the carcass of Morada Nova lambs fed different dietary ratios of forage and concentrate. Revista Brasileira de Zootecnia, v.35, p.1487-1495, 2006.

KOSULWAT, S.; GREENFIELD, H.; JAMES, J. Lipid composition of Australian retail lamb cuts with differing carcass classification characteristics. Meat Science, v.65, p.1413-1420, 2003.

MACEDO, F.A.F.; SIQUEIRA, E.R.; MARTINS, E.N. et al. Carcass Auality of Corriedale, Bergamacia x Corriedale, and Hampshire Down x corriedale Lambs, Finished on Pasture or Dry-Lot. Revista Brasileira de Zootecnia, v.29, p.1520-1527, 2000.

NATIONAL RESEARCH COUNCIL - NRC. Nutrient requirements of domestic animals: nutrient requirements of sheep. 6.ed. Washington: National Academy, 1985. 99p.

OLIVEIRA, N.M.; OSÓRIO, J.C.S.; MONTEIRO, E.M. Produção de carne em ovinos de cinco genótipos. 4. Composição regional e tecidual. Ciência Rural, v.28, p.125-129. 1998.

OSORIO, J.C.S.; OSORIO, M.T.M. Produção de carne ovina: Técnicas de avaliação "in vivo" e na carcaça. Pelotas: UFPel, 2003. 73p.

PURCHAS, R.W.; DAVIES, A.S.; ABDUKKAH, A.Y. An objective measure of muscularity: changes with animal growth and differences between genetic lives of Southdown sheep. Meat Science, v.30, p.81-94, 1991.

SA, J.L.; SIQUEIRA, E.R.; SA, C.O. et al. Características de carcaça de cordeiros Hampshire Down e Santa Inês sob diferentes fotoperíodos. Pesquisa Agropecuária Brasileira, v.40, p.289-297, 2005.

SAFARI, E.; HOPKINS, D.L.; FOGARTY, N.M. Diverse lamb genotoypes 4 . Predicting the yield of saleable meat and high value trimmed cuts from carcass measurements. Meat Science, v.58, p.207-214, 2001

SAÑUDO, C.; ALFONSO, M.; SANCHEZ, A. et al. Carcass end meat quality in light lambs from different fat classes in the EU carcass classification system. Meat Science, v.56, p.89-94, 2000.

SEN, A.R.; SANTRA, A.; KARIM, S.A. Carcass yield, composition and meat quality attributes of sheep and goat under semiarid conditions. Meat Science, v.66, p.757-763. 2004.

SIQUEIRA, E.R.; SIMÕES, C.D.; FERNANDES, S. Sex and slaughter weight effects on meat production of lambs. Carcass morphometric evaluation, cuts weights, tissues and offals percentages. Revista Braileira de Zootecnia, v.30, p.1299-1307, 2001.

STATISTICAL ANALYSIS SYSTEMS - SAS. User's guide: Statistics. Versão 6.12. Cary: Caroline State University, 1999. (CD-ROM). 